\title{
Management of Fire Blight Using Pre-bloom Application of Prohexadione-Calcium
}

\author{
Anna E. Wallis and Kerik D. Cox ${ }^{\dagger}$ \\ Department of Plant Pathology and Plant-Microbe Biology, Cornell AgriTech, Cornell University, Geneva, NY 14456
}

\begin{abstract}
Fire blight, a bacterial disease of rosaceous plants caused by Erwinia amylovora, is one of the most important diseases affecting commercial apple production worldwide. Antibiotics, applied at bloom to protect against blossom infection, are the most effective means of management but raise concern due to the potential for antibiotic resistance in both the pathogen population and nontarget organisms. In addition, most fire blight outbreaks in New York State often emerge in late June to July as shoot blight, calling into question the role of blossom infections and the antibiotic applications made to manage them. Prohexadione-calcium $(\mathrm{PhCa})$ is a gibberellic acid inhibitor used post-bloom to control shoot vigor and to manage shoot blight. However, the magnitude of shoot blight management is directly related to the suppression of shoot growth, which is undesirable, especially in young orchards during establishment years. $\mathrm{PhCa}$ is believed to control shoot blight by thickening cell walls in cortical parenchyma, preventing invasion of host tissues by E. amylo-

their effects on disease management (blossom and shoot blight) as well as their impact on shoot growth for three years in a mature 'Gala' orchard in New York. In all three years of the study, all $\mathrm{PhCa}$ programs resulted in less than $27 \%$ incidence ( $71 \%$ control) of blossom blight and less than $13 \%$ incidence (77\% control) of shoot blight with minimal effect on tree growth. Inclusion of a biopesticide during bloom further reduced the incidence of blossom blight in one year of three. Using light microscopy, we found that cell walls in the cortical parenchyma of fruitlet pedicels on trees receiving pre-bloom $\mathrm{PhCa}$ applications were significantly thicker than those of untreated trees 40 days after full bloom and inoculation. Overall, we found that pre-bloom applications of $\mathrm{PhCa}$ had utility in reducing blossom blight and shoot blight with minimal impacts on tree growth. These pre-bloom programs would fit with standard production practices and may contribute toward the development of fire blight management programs without the use of antibiotics.
\end{abstract} vora. We hypothesize that $\mathrm{PhCa}$ applied pre-bloom could similarly prevent invasion of blossom pedicels following infection, leading to reduced disease incidence. We evaluated novel pre-bloom $\mathrm{PhCa}$ programs for
Keywords: Erwinia amylovora, Malus $\times$ domestica, pink, Apogee, plant growth regulator
Fire blight, caused by the bacterial pathogen Erwinia amylovora, is one of the most destructive diseases of commercial apple production worldwide. Originally identified in the Hudson Valley of New York in the early 1800s and formally described by Thomas Burrill in 1880, fire blight is still a major source of grower consternation and an active area of research for nearly two centuries (van der Zwet et al. 2012). Fire blight has spread to nearly every apple production region worldwide, with the exception of parts of South America, Africa, and Asia (van der Zwet et al. 2012), and is capable of destroying entire orchard blocks in a single season (Norelli 2003; van der Zwet et al. 2012). Economic losses in the United States are estimated at over $\$ 100$ million annually; most recently, fire blight outbreaks in the Champlain Valley of New York in 2016 and southwest Michigan in 2000 and 2005 impacted most commercial farms in the regions with total economic losses estimated at $\$ 23,465$ per hectare and $\$ 42$ million across a region (Elizabeth Higgins personal communication; Norelli 2003). In recent years, fire blight has become particularly problematic due to the adoption of high-density orchards composed of smaller trees and popular cultivars, which are more susceptible to the disease and sustain the most damage from infection.

E. amylovora is a gram-negative bacterium in the Enterobacteriaceae family and is classified as a hemibiotroph. The bacteria may persist in living host tissue at the margin of cankers from old infection sites. In the spring under warm, humid conditions, cankers produce

\section{${ }^{\dagger}$ Corresponding author: K. D. Cox; kdc33@ cornell.edu}

Funding: This research was supported in part by state, federal, and institutional funding appropriated by the NY State Apple Research and Development Program (OSP \#90000) and Northeast SARE (LNE19-385R-33243).

The author(s) declare no conflict of interest.

Accepted for publication 11 November 2019.

(C) 2020 The American Phytopathological Society a sticky bacterial ooze; bacteria rapidly colonize the plant surface and are transferred to the stigmatic surface of the flower by insects and rain splash. Primary infection occurs during bloom, when bacteria are washed into the flowers through nectaries in the hypanthium, invading the blossom and pedicel, causing blight of the flowers in the flower cluster, leading to blossom blight (van der Zwet et al. 2012). A secondary form of infection is shoot blight, in which shoots become infected by bacterial ooze from cankers or blighted flowers entering wounds caused by wind, hail, or insects (van der Zwet et al. 2012).

For over 40 years, the most effective tool for the management of blossom blight has been the application of the aminoglycoside antibiotic streptomycin (Norelli 2003). More recently, kasugamycin, another aminoglycoside antibiotic, has also been registered in several states for fire blight management in orchards, in response to the emergence of streptomycin-resistant $E$. amylovora (EPA registration number 66330-404; McGhee and Sundin 2011). Antibiotics are applied to open blossoms with guidance on application timing provided by one of several weather-based models (i.e., Maryblyt, CougarBlight), which were developed to predict risk of infection events (Biggs and Turechek 2010; Carroll et al. 2017; Smith 1999; Turechek and Biggs 2015). Streptomycin routinely provides $>90 \%$ reduction of disease incidence in trials in the northeastern United States (Aldwinckle et al. 2002; Norelli 2003). The use of antibiotics in agriculture has come under public scrutiny due to the potential for selection of streptomycin resistance in both pathogen populations and nontarget bacteria (McManus et al. 2002). Streptomycin-resistant E. amylovora was first reported in 1971 in California (Miller and Scroth 1972) and has since been identified in most major production regions in the United States, including Washington, Oregon, Michigan, and New York (Loper et al. 1991; McGhee et al. 2011; McManus and Jones 1994; Russo et al. 2008; Tancos and Cox 2016). Additionally, antibiotic use has been prohibited in organic production in the United States since 2014; this is consistent with organic regulations in other locations, including Canada and the European Union (Johnson and Temple 2013). In this regard, alternative management strategies are necessary for the sustainable management of fire blight. 
Additionally, antibiotics may not be the most appropriate management tool for all phases of fire blight. Typically, the focus of commercial fire blight management programs is the blossom blight phase, because infected blossoms can produce inoculum for secondary shoot blight infections observed during the summer. However, blossom blight is difficult to manage: it requires extremely precise management because the opportune application period occurs during a host phenological stage that may last only a few days, symptoms are less obvious and easily overlooked, and very low incidences of infected blossoms are capable of producing inoculum for secondary infection. As a result, fire blight is usually reported as shoot blight in late June to July - rather than blossom blight, which would occur earlier in the spring - as evidenced by recent statewide fire blight surveys, in which fire blight samples were solicited from growers (Tancos and Cox 2016). It is generally believed that shoot blight is more frequently reported in commercial orchards because symptoms are more easily identified, especially during periods of vigorous shoot growth. In this regard, should growers focus on managing both blossom and shoot blight earlier, prior to bloom, and should materials other than antibiotics be investigated?

A plant growth regulator like prohexadione-calcium $(\mathrm{PhCa})$ could be used to manage both blossom and shoot blight prior to infection. $\mathrm{PhCa}$ is a gibberellic acid inhibitor, originally registered for apple production in the United States in 1999 with the primary commercial use of canopy management and reduction of shoot vigor (Evans et al. 1999). Current recommendations for vegetative growth control are to apply 125 to $250 \mathrm{mg} / \mathrm{liter}$ for mature trees or 62.5 to $125 \mathrm{mg} / \mathrm{liter}$ for trees less than 5 years, at petal fall and again 14 to 21 days later, timing that corresponds with early season shoot growth (Evans et al. 1999). Early in development, it was discovered that $\mathrm{PhCa}$ also was effective for managing fire blight (Breth et al. 1998; Jones et al. 1999; Yoder et al. 1999). Extensive investigations led to the discovery that $\mathrm{PhCa}$ applications were able to reduce shoot blight incidence from 40 to $90 \%$ when applied in a field setting with either natural or artificial bacterial inoculation; investigations usually evaluated one or two applications of 125 and $250 \mathrm{mg} / \mathrm{liter}$, with a single high-rate application typically providing the best disease control (Aldwinckle et al. 2000; Bazzi et al. 2003; Costa et al. 2001; Norelli and Miller 2004, 2006). Application timing is critical for effective fire blight management and coincides with application timing for vegetative growth control (Evans et al. 1999; Rademacher et al. 2006). Most studies have found that $\mathrm{PhCa}$ must be applied at least 7 to 10 days prior to infection or inoculation in order to reduce incidence of shoot blight; therefore, current recommendations are to make one or two applications of 125 or $250 \mathrm{mg} /$ liter beginning at petal fall or when 5 to $8 \mathrm{~cm}$ of shoot growth are observed (Agnello et al. 2019; Aldwinckle et al. 2000; Costa et al. 2001; Schupp et al. 2002; Yoder et al. 1999). Unsurprisingly, the magnitude of shoot blight management was directly related to the suppression of shoot growth, a problem for young orchards in which vigorous growth is encouraged as trees are pushed to fill canopy space. Therefore, prior research has concluded that $\mathrm{PhCa}$ 's negative impacts on tree growth prohibit its use for shoot blight control in young orchards, and it is primarily reserved for shoot blight control in mature orchards under high disease pressure (Aldwinckle et al. 2002; Costa et al. 2004; Norelli and Miller 2004, 2006).

Originally, the mechanism of action for shoot blight control was believed to be via the production of novel antibiotic compounds within the host, the result of an altered flavonoid biosynthetic pathway (Halbwirth et al. 2003; Rademacher et al. 2006; Roemmelt et al. 2003; Spinelli et al. 2005). However, novel compounds did not show an appreciable effect on bacterial growth (Roemmelt et al. 2003), and transgenic apples with an altered flavonone pathway mimicking that of $\mathrm{PhCa}$-treated plants did not produce adequate metabolic changes to reduce fire blight susceptibility (Flachowsky et al. 2012). Other proposed mechanisms of action included physiological resistance as well as morphological and histological changes (Bazzi et al. 2003). More recent work has found reduced pathogen migration within the leaf xylem and parenchyma tissue in vitro (Spinelli et al. 2006) and evidence for physical inhibition of bacteria within the host through the thickening of cell walls in the cortical parenchyma tissue to the point where E. amylovora's type III secretion systemassociated pilus is prevented from delivering effectors (McGrath et al. 2009).

Investigation of $\mathrm{PhCa}$ applied earlier in the season (pre-bloom) for both shoot blight and blossom blight has been limited due to label restrictions, the need for preinfection applications, and the limited leaf surface area available before bloom (Evans et al. 1999; Rademacher and Kober 2003). However, a few reports demonstrate distinct potential for PhCa-mediated blossom blight protection and early shoot blight protection, if applied pre-bloom (Buban et al. 2006; Spinelli et al. 2006) or postharvest, leading to carryover effects in the following season (Greene 2005). In addition, there is growing interest in the industry and extension to evaluate $\mathrm{PhCa}$ for control of blossom blight. Novel uses, including pre-bloom applications, could prevent invasion of the blossom tissues through the mechanism of cell wall thickening. Applying $\mathrm{PhCa}$ at lower rates for blossom blight control may allow for protection without inhibiting canopy growth by the end of the season. The paucity of academic research on the use of $\mathrm{PhCa}$ for blossom blight and early shoot blight management has led to increased reliance on extension publications, technical reports, and anecdotal reports from the industry to highlight research needs and drive hypotheses for academic research.

The objective of this work was to evaluate pre-bloom $\mathrm{PhCa}$ programs for fire blight management. Specifically, we evaluated $\mathrm{PhCa}$ applied at "pink," the phenological stage of apple preceding bloom, in which the flowers are beginning to open and show a magenta coloration (Meier 2001), for impacts on fire blight (blossom and shoot blight) as well as impacts on tree growth. We hypothesized that these $\mathrm{PhCa}$ programs would reduce disease incidence of blossoms and shoots through the mechanism of cell wall thickening, without negatively impacting tree growth. Such management programs would fit with standard production practices for apple and may be a step toward the development of fire blight management programs without the use of antibiotics.

\section{Materials and Methods}

Evaluation of pre-bloom programs of $\mathrm{PhCa}$ for blossom blight and shoot blight management. To evaluate the effects of novel $\mathrm{PhCa}$ programs for fire blight management, field trials were conducted at Cornell AgriTech in a research orchard in Geneva, NY $\left(42^{\circ} 87^{\prime} 70.19^{\prime \prime} \mathrm{N}, 77^{\circ} 02^{\prime} 99.15^{\prime \prime} \mathrm{W}\right)$ over three field seasons: 2016 , 2017, and 2018. Experiments were performed in a planting of 'Buckeye Gala' on B.9 rootstock, planted in 2000 at $1.8-\mathrm{m}$ in-row spacing. Trees exhibited moderate vigor; fertilization and pruning were maintained according to the Cornell Pest Management Guidelines (Agnello et al. 2019). A randomized complete block design with four single-tree replications was used to evaluate the management programs (Table 1). All applications were made using a Solo 475-B gas-powered mist blower (Solo, Newport News, VA) calibrated to deliver approximately 935.3 liters/ha, a standard volume for highdensity apple plantings in the northeastern United States. To evaluate pre-bloom programs of $\mathrm{PhCa}$ for managing blossom blight, applications began at pink. In these programs Apogee (BASF Corporation, Research Triangle Park, NC) was applied at either 62.5 or $125 \mathrm{mg}$ / liter, reflecting low and reduced label rates for fire blight control. $\mathrm{PhCa}$ was either applied on its own at pink, or it was followed with an application of the biopesticide Double Nickel LC (DN; Certis, Columbia, MD) at $2.34 \mathrm{~kg} / \mathrm{ha}$ to protect blossoms during this critical infection period in these programs, at $80 \%$ bloom. In addition to the $\mathrm{PhCa}$ programs, two control programs (positive and negative) were included: (i) untreated control plots were included to serve as a negative control and indicator of overall disease pressure, and (ii) antibiotic programs were included as a positive control and industry standard, in which the antibiotics streptomycin and kasugamycin were applied at $80 \%$ bloom. In these programs, FireWall 17WP (AgroSource, Mountainside, NJ) and Kasumin 2L (Arysta LifeScience, Cary, NC) were applied at the label rates of $1.68 \mathrm{~kg} / \mathrm{ha}$ and 5 liters/ha respectively, with the nonionic surfactant Regulaid (KALO, Overland Park, KS) applied at 3.18 liters/ha. Specific 
application times included pink (3 May, 27 April, and 11 May) and 80\% bloom (11 May, 9 May, and 18 May) in 2016, 2017, and 2018, respectively.

To ensure adequate disease pressure, trees were inoculated with $E$. amylovora strain Ea273, a highly aggressive strain originally isolated from trees in New York State, routinely used in laboratory and field trials (Lee et al. 2010). Cultures were stored in $50 \%$ glycerol at $-80^{\circ} \mathrm{C}$ prior to use, streaked on Luria-Bertani agar, and incubated at $28^{\circ} \mathrm{C}$ for 3 days. Cultures were then resuspended in Luria-Bertani broth overnight while shaken at $28^{\circ} \mathrm{C}$, and suspensions were diluted to $1 \times 10^{6} \mathrm{CFU} / \mathrm{ml}$ in phosphate buffered saline immediately prior to inoculation. Inoculum was applied using a hand-pumped Solo 475-B backpack sprayer at 80 to $90 \%$ bloom. Inoculation was performed on 11 May, 10 May, and 18 May in 2016, 2017, and 2018, respectively. Inoculations were performed within $24 \mathrm{~h}$ of bloom pesticide applications, after drying. Weather conditions at the time of inoculation included daily mean and high temperatures of 8.7 and $11.9^{\circ} \mathrm{C}$, 6.4 and $11.5^{\circ} \mathrm{C}$, and 10.1 and $15.5^{\circ} \mathrm{C}$ in 2016,2017 , and 2018 , respectively, with wind speed less than $9 \mathrm{~km} / \mathrm{h}$ in all years. In all three years, a wetting event occurred within the 3 days following inoculation, in which $0.84,0$, and $1.5 \mathrm{~cm}$ of accumulation was recorded in respective years; leaf wetness ranged from 1 to $19 \mathrm{~h}$; and 10 to $32 \mathrm{~h}$ of relative humidity $>90 \%$ was recorded. Blighted clusters served as inoculum for shoot blight infections. To assess efficacy of pre-bloom programs for fire blight management, symptoms were assessed on blossom clusters (number of flowers blighted per cluster) and terminal shoots (shoot tip infections) in June. Disease was rated as early as symptoms were reliably detectable, for blossom blight on 3 June, 3 June, and 13 June, and for shoot blight on 30 June, 30 June, and 3 July in 2016, 2017, and 2018, respectively. The incidence of blossom or shoot blight was expressed as the number of blighted flowers per cluster or terminal shoots blighted out of 20 assessments for four replicate trees per treatment. To preserve trees, disease strikes were pruned out midsummer following disease ratings.

Investigating PhCa-induced cell wall thickening as the mechanism of action providing blossom blight control. To investigate the mechanism of action of $\mathrm{PhCa}$ in reduction of blossom blight incidence in pre-bloom programs, we evaluated cell wall thicknesses in pedicels of developing flowers and fruitlets in 2018 and 2019, using methods adapted from McGrath et al. (2009). In each year, PhCa was applied at $0,62.5$, and $125 \mathrm{mg} /$ liter at pink as previously described. Measurements were taken at two times during the season: (i) after petal fall, approximately 20 days after $\mathrm{PhCa}$ treatments when treatment effects should have first been visible, and (ii) approximately 40 days after full bloom (DAFB) or 50 days after PhCa treatments. Specific collection times included 4 June and 27 June in 2018 (24 and 47 days after pink application), and 3 June and 27 June in 2019 (24 and 48 days after pink application). In 2018, measurements were also taken at pink ( 0 days after treatment), and no significant difference was found between treatments (data not shown). At each time point, king blossoms or fruitlets were randomly selected for each treatment replication, transported in plastic Ziploc bags to the laboratory (within $1 \mathrm{~h}$ ), held at $40^{\circ} \mathrm{C}$, and processed within $24 \mathrm{~h}$ of collection. The pedicel was separated from the flower or fruitlet and cross-sectioned by hand at the midpoint. Thin cross sections (approximately one cell thick) were made under a dissection microscope by holding the pedicel steady between two microscope slides and making slices perpendicular to the stem with a double-edged razor blade (Personna, Staunton, VA). Wet mounts were constructed, and prepared slides were imaged using a light microscope (model BX50, Olympus, Webster, NY). Digital images were taken at 400× magnification using SPOT Basic Imaging Software version 5.3 (Fig. 1; SPOT Imaging, Diagnostic Instruments, Sterling Heights, MI). Fifty total cell wall measurements were made within the cortical parenchyma tissue directly below the epidermal tissue for each treatment replicate.

Evaluation of pre-bloom program of $\mathrm{PhCa}$ for tree growth. To assess effects of pre-bloom $\mathrm{PhCa}$ programs on tree growth, shoot growth was evaluated each year. Measurements were made at two points during the season: once in July at approximately terminal bud set, the point at which trees stop putting on significant vegetative growth (5 July, 6 July, and 6 July in 2016, 2017, and 2018), and once in September, following harvest when growth is concluded for the season (22 September, 21 September, and 21 September). To evaluate shoot length, the current season's growth (bud scale scar to attachment point of terminal leaf) was measured for 20 randomly selected healthy shoots in each treatment replication.

Data analysis. Disease incidence and host response data were subjected to analysis of variance (ANOVA) for a randomized block design using the generalized linear mixed models (GLIMMIX) procedure of SAS (version 9.4; SAS Institute, Cary, NC). All percentage data were subjected to arcsine square-root transformation prior to analysis. Cell wall thickness data were also evaluated using ANOVA for randomized block design using the GLIMMIX procedure of SAS 9.4. For models with significant fixed effects, differences between treatments were determined using the LSMEANS procedure in SAS 9.4 at the $\alpha=0.05$ level of significance with an adjustment for Tukey's HSD to control for family-wise error.
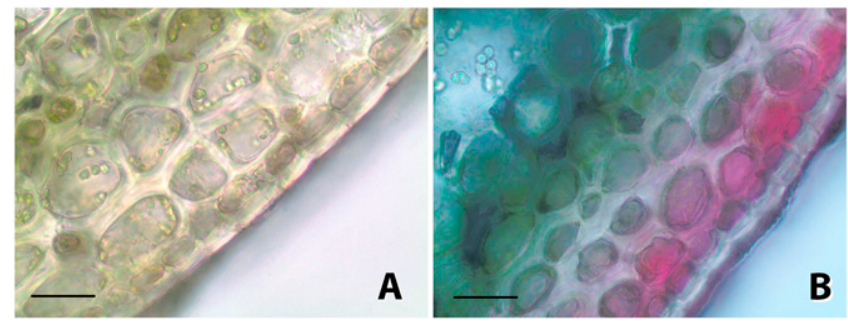

Fig. 1. Hand cross sections of apple fruitlet pedicels at 50 days post-treatment (40 days after full bloom) for trees treated with $0 \mathrm{~g} /$ liter $(\mathbf{A})$ and $125 \mathrm{~g} /$ /iter (B) of prohexadione-calcium. Fifty random cell wall measurements were taken in the cortical parenchyma tissue just below the epidermis from a minimum of 25 pedicels for each replication. Cell wall thickness in treated trees was significantly greater than cell wall thickness of untreated trees. Coloration reflects natural pigmentation of the pedicels at the time of sampling. Scale bars represent $50 \mu \mathrm{m}$.

Table 1. Summary of pre- and post-bloom treatments evaluated for fire blight protection and shoot growth in 2016, 2017, and 2018

\begin{tabular}{|c|c|c|}
\hline Treatment and rate & Time $^{\mathbf{z}}$ & Active ingredient \\
\hline \multicolumn{3}{|l|}{ Control programs } \\
\hline Untreated & $\ldots$ & $\ldots$ \\
\hline Bloom FireWall $171.68 \mathrm{~kg} / \mathrm{ha}$ & Bloom & Streptomycin \\
\hline Bloom Kasumin 4.7 liters/ha & Bloom & Kasugamycin \\
\hline \multicolumn{3}{|c|}{ Pre-bloom prohexadione-calcium ( $\mathrm{PhCa}$ ) programs } \\
\hline Pink Apogee $62.5 \mathrm{mg} / \mathrm{liter}$ & Pink & $\mathrm{PhCa}$ \\
\hline $\begin{array}{l}\text { Pink Apogee } 62.5 \mathrm{mg} / \mathrm{liter} \text { and bloom } \\
\text { Double Nickel LC } 2.34 \mathrm{~kg} / \mathrm{ha}\end{array}$ & Pink and bloom & $\mathrm{PhCa}$ and Bacillus amyloliquefaciens \\
\hline Pink Apogee 125 mg/liter & Pink & $\mathrm{PhCa}$ \\
\hline $\begin{array}{l}\text { Pink Apogee } 125 \mathrm{mg} / \text { liter and bloom } \\
\text { Double Nickel LC } 2.34 \mathrm{~kg} / \mathrm{ha}\end{array}$ & Pink and bloom & $\mathrm{PhCa}$ and Bacillus amyloliquefaciens \\
\hline
\end{tabular}




\section{Results}

Evaluation of pre-bloom programs of PhCa for blossom and shoot blight management. Blossom blight was observed in each year, following blossom inoculation, with the highest incidence occurring in 2017. Blossom blight incidence for untreated control trees was $65 \pm 4 \%, 94 \pm 2 \%$, and $55 \pm 3 \%$ in 2016, 2017, and 2018, respectively (Table 2). Shoot blight also developed following inoculation of blossoms in the each of the three years. The incidence of shoot blight in the untreated controls was $24 \pm 4 \%, 55 \pm 3 \%$, and $28 \pm 3 \%$ in 2016 , 2017, and 2018, respectively (Table 2). In all three years, there was a significant effect of treatment on the incidence of blossom blight $(P<$ $0.0001)$ and shoot blight $(P<0.0001)$.

Both antibiotic programs provided excellent control with less than $4 \%$ blossom blight incidence; the only exception was kasugamycin in 2018 (12\% incidence), but this was not significantly different than the streptomycin program (Table 2). Blossom blight incidence for the streptomycin treatment was $3.9 \pm 1.8 \%, 3.3 \pm 3.1 \%$, and $1.6 \pm 0.4 \%$ in 2016, 2017, and 2018, respectively. In kasugamycin programs, blossom blight incidence was $2.0 \pm 0.4 \%, 0.9 \pm 0.9 \%$, and $12.1 \pm$ $6.3 \%$ in the three years. Shoot blight incidence for streptomycin treatment was $0.0 \pm 0.0 \%, 0.0 \pm 0.0 \%$, and $0.6 \pm 0.6 \%$ in 2016, 2017, and 2018 respectively. For kasugamycin programs, shoot blight incidence was $0.7 \pm 0.4 \%, 2.4 \pm 1.9 \%$, and $3.2 \pm 1.9 \%$ in the three years.

There were no significant differences in the incidence of fire blight between any of the pre-bloom $\mathrm{PhCa}$ programs in any of the three years, with the incidence of blossom blight and shoot blight less than 27 and 13\%, respectively $(P>0.05$, Table 2$)$. Although not significant, the program in which $125 \mathrm{mg} /$ liter of $\mathrm{PhCa}$ was applied at pink and the biopesticide DN was applied at bloom tended to have lower incidences of blossom blight and shoot blight. Linear contrast analysis did indicate that in 2017 there was a significant reduction in blossom blight incidence when DN application followed the $62.5 \mathrm{mg} /$ liter $\mathrm{PhCa}$ application $(P<0.0001)$, and there was a significant reduction for both the 62.5 and $125 \mathrm{mg} /$ liter rates of $\mathrm{PhCa}$ when DN was included in the program $(P=0.0266$ and $P=0.0088)$. Linear contrast analysis comparing $\mathrm{PhCa}$ alone versus with the addition of DN was not significant for 2016 or $2018(P>0.05)$. All pre-bloom $\mathrm{PhCa}$ treatments had a lower incidence of blossom blight than the untreated controls. In 2016, the incidence of blossom blight in prebloom PhCa programs was higher than that for the two antibiotic controls. By contrast, in 2017 and 2018, there were no significant differences in the incidence of blossom blight between pre-bloom $\mathrm{PhCa}$ programs and the antibiotic programs. Shoot blight in pre-bloom $\mathrm{PhCa}$ programs in 2017 and 2018 generally was higher than in the streptomycin program but not in the kasugamycin program.

Evidence for PhCa-induced cell wall thickening as the mechanism of action providing blossom blight control. There was an effect of treatment program on cell wall thickness in the pedicel at the majority of sampling times (Fig. 2). In 2018, trees treated with $\mathrm{PhCa}$ at pink did not have thicker cell walls than the untreated control trees at petal fall (e.g., shortly after the treatment, $P=0.0515$ ), but trees treated with 62.5 or $125 \mathrm{mg} /$ liter of $\mathrm{PhCa}$ at 40 DAFB both had thicker cell walls than untreated trees $(P=0.0006)$. In 2019 , trees receiving 62.5 or $125 \mathrm{mg} / \mathrm{liter}$ of $\mathrm{PhCa}$ at pink had thicker cell walls

Table 2. Mean disease incidence and shoot growth of Gala trees treated with pre-bloom fire blight programs utilizing prohexadione-calcium (Apogee) at the Cornell AgriTech research orchards in Geneva, NY, in 2016, 2017, and 2018

\begin{tabular}{|c|c|c|c|c|}
\hline Treatment & Blossom blight $(\%)^{\mathrm{w}}$ & Shoot blight $(\%)^{\mathrm{x}}$ & Shoot length July $(\mathrm{mm})^{\mathrm{y}}$ & Shoot length September $(\mathbf{m m})^{y}$ \\
\hline \multicolumn{5}{|l|}{2016} \\
\hline Untreated & $65.0 / 0 \mathrm{a}^{\mathrm{z}}$ & $23.9 / 0 \mathrm{a}$ & $308.5 \mathrm{a}$ & $330.4 \mathrm{a}$ \\
\hline Bloom FireWall $171.68 \mathrm{~kg} / \mathrm{ha}$ & $3.9 / 94.0 \mathrm{~cd}$ & $0.0 / 100 \mathrm{c}$ & $221.7 \mathrm{~b}$ & $316.8 \mathrm{abc}$ \\
\hline Bloom Kasumin 4.7 liters/ha & $2.0 / 96.9 \mathrm{~d}$ & $0.7 / 97.1 \mathrm{bc}$ & $277.0 \mathrm{ab}$ & $298.1 \mathrm{bc}$ \\
\hline Pink Apogee $62.5 \mathrm{mg} /$ liter & $25.6 / 60.6 \mathrm{~b}$ & $6.3 / 73.6 \mathrm{bc}$ & $265.0 \mathrm{ab}$ & $255.5 \mathrm{c}$ \\
\hline $\begin{array}{l}\text { Pink Apogee } 62.5 \mathrm{mg} / \mathrm{liter} \text { and bloom } \\
\text { Double Nickel LC } 2.34 \mathrm{~kg} / \mathrm{ha}\end{array}$ & $22.8 / 64.9 \mathrm{~b}$ & $5.3 / 77.8 \mathrm{~b}$ & $258.3 \mathrm{ab}$ & $256.7 \mathrm{c}$ \\
\hline Pink Apogee 125 mg/liter & $15.3 / 76.5 \mathrm{~b}$ & $3.9 / 83.7 \mathrm{bc}$ & $260.6 \mathrm{ab}$ & $255.4 \mathrm{bc}$ \\
\hline $\begin{array}{l}\text { Pink Apogee } 125 \mathrm{mg} / \mathrm{liter} \text { and bloom } \\
\text { Double Nickel LC } 2.34 \mathrm{~kg} / \mathrm{ha}\end{array}$ & $12.5 / 80.8 \mathrm{bc}$ & $5.4 / 77.4 \mathrm{~b}$ & $229.8 \mathrm{~b}$ & $179.6 \mathrm{~d}$ \\
\hline$P$ values & $<0.0001$ & $<0.0001$ & $<0.0001$ & $<0.0001$ \\
\hline \multicolumn{5}{|l|}{2017} \\
\hline Untreated & $94.4 / 0 \mathrm{a}$ & $55.0 / 0 \mathrm{a}$ & $207.9 \mathrm{~b}$ & $239.9 \mathrm{~b}$ \\
\hline Bloom FireWall $171.68 \mathrm{~kg} / \mathrm{ha}$ & $3.3 / 96.4 \mathrm{~b}$ & $0.0 / 100 \mathrm{bc}$ & $292.1 \mathrm{ab}$ & $293.3 \mathrm{a}$ \\
\hline Bloom Kasumin 4.7 liters/ha & $0.9 / 99.0 \mathrm{~b}$ & $2.4 / 95.7 \mathrm{c}$ & $308.3 \mathrm{a}$ & $339.1 \mathrm{ab}$ \\
\hline Pink Apogee 62.5 mg/liter & $26.9 / 71.4 \mathrm{~b}$ & $11.5 / 79.1 \mathrm{~b}$ & $278.9 \mathrm{ab}$ & $321.4 \mathrm{ab}$ \\
\hline $\begin{array}{l}\text { Pink Apogee } 62.5 \mathrm{mg} / \mathrm{liter} \text { and bloom } \\
\text { Double Nickel LC } 2.34 \mathrm{~kg} / \mathrm{ha}\end{array}$ & $10.7 / 88.7 \mathrm{~b}$ & $4.3 / 92.3 \mathrm{bc}$ & $289.5 \mathrm{a}$ & $292.1 \mathrm{ab}$ \\
\hline Pink Apogee $125 \mathrm{mg} /$ liter & $13.2 / 86.0 \mathrm{~b}$ & $12.9 / 76.7 \mathrm{~b}$ & $259.6 \mathrm{ab}$ & $277.7 \mathrm{ab}$ \\
\hline $\begin{array}{l}\text { Pink Apogee } 125 \mathrm{mg} / \text { liter and bloom } \\
\text { Double Nickel LC } 2.34 \mathrm{~kg} / \mathrm{ha}\end{array}$ & $6.4 / 93.2 \mathrm{~b}$ & $6.4 / 88.5 \mathrm{bc}$ & $277.3 \mathrm{ab}$ & $281.1 \mathrm{ab}$ \\
\hline$P$ values & $<0.0001$ & $<0.0001$ & $<0.0001$ & $<0.0001$ \\
\hline \multicolumn{5}{|l|}{2018} \\
\hline Untreated & $55.2 / 0 \mathrm{a}$ & $27.8 / 0 \mathrm{a}$ & $206.0 \mathrm{~d}$ & $299.7 \mathrm{c}$ \\
\hline Bloom FireWall $171.68 \mathrm{~kg} / \mathrm{ha}$ & $1.6 / 97.1 \mathrm{~b}$ & $0.6 / 97.8 \mathrm{~b}$ & $311.8 \mathrm{a}$ & $318.0 \mathrm{bc}$ \\
\hline Bloom Kasumin 4.7 liters/ha & $12.1 / 78.1 \mathrm{~b}$ & $3.2 / 88.6 \mathrm{~b}$ & $311.9 \mathrm{a}$ & $306.2 \mathrm{bc}$ \\
\hline Pink Apogee $62.5 \mathrm{mg} /$ liter & $13.5 / 75.4 \mathrm{~b}$ & $2.0 / 92.7 \mathrm{~b}$ & $282.6 \mathrm{ab}$ & $360.3 \mathrm{ab}$ \\
\hline $\begin{array}{l}\text { Pink Apogee } 62.5 \mathrm{mg} / \mathrm{liter} \text { and bloom } \\
\text { Double Nickel LC } 2.34 \mathrm{~kg} / \mathrm{ha}\end{array}$ & $14.4 / 73.9 \mathrm{~b}$ & $4.7 / 83.0 \mathrm{~b}$ & $268.6 \mathrm{abc}$ & $400.4 \mathrm{a}$ \\
\hline Pink Apogee $125 \mathrm{mg} /$ liter & $15.0 / 72.8 \mathrm{~b}$ & $5.2 / 81.2 \mathrm{~b}$ & $228.0 \mathrm{~cd}$ & $312.4 \mathrm{bc}$ \\
\hline $\begin{array}{l}\text { Pink Apogee } 125 \mathrm{mg} / \text { liter and bloom } \\
\text { Double Nickel LC } 2.34 \mathrm{~kg} / \mathrm{ha}\end{array}$ & $8.8 / 84.1 \mathrm{~b}$ & $3.2 / 88.4 \mathrm{~b}$ & $243.3 \mathrm{bcd}$ & $308.0 \mathrm{bc}$ \\
\hline$P$ values & $<0.0001$ & $<0.0001$ & $<0.0001$ & $<0.0001$ \\
\hline
\end{tabular}

${ }^{\mathrm{w}}$ Percent incidence/percent control of blossom blight, number of blighted blossoms per cluster for 20 blossom clusters rated.

$\mathrm{x}$ Percent incidence/percent control of shoot blight for 20 terminal shoots rated.

y Mean length of current season's growth for 20 shoots.

$\mathrm{z}$ Values within columns for a given year followed by the same letter are not significantly different $(P<0.05)$ according to the LSMEANS procedure in SAS 9.4 with an adjustment for Tukey's HSD to control for family-wise error. 
than untreated trees at petal fall $(P<0.0001)$ and 40 DAFB $(P<$ 0.0001).

Evaluation of pre-bloom programs of $\mathrm{PhCa}$ on tree growth. A minimal impact was observed on shoot length for all programs across the three years $(P<0.0001$ for all three years), with reductions in growth being approximately 10 to $15 \mathrm{~cm}$ for both July and September measurements. In untreated control trees, growth tended to be lower because trees experience higher levels of shoot blight; therefore, the antibiotic treatments were used for shoot growth comparisons. Pre-bloom PhCa programs rarely differed in shoot length from the antibiotic programs in either July or September, with only two exceptions. In 2016, $125 \mathrm{mg} /$ liter of $\mathrm{PhCa}$ followed by the biopesticide at bloom had shorter shoot growth than both antibiotic programs. In 2018, $125 \mathrm{mg} /$ liter of PhCa without a bloom biopesticide application had shorter shoot growth than both antibiotics $(P<$ $0.0001)$.

\section{Discussion}

Management of fire blight with antibiotics has become a tenuous topic, and presently there is demand for alternative management programs. This is especially true for temperate production regions, where antibiotic alternative management programs developed for arid apple production regions (Johnson and Temple 2013) have been unable to reliably provide acceptable levels of control (Aldwinckle et al. 2002; Sundin et al. 2009). PhCa is currently recommended for shoot blight control in mature orchards after petal fall during the period of shoot elongation (Agnello et al. 2019; Aldwinckle et al. 2000, 2002; Norelli and Miller 2006, 2004; Yoder et al. 1999). There have also been cursory studies investigating potential for its use earlier in the season and at lower rates for control of blossom blight and preemptive management of shoot blight (Buban et al. 2006; Greene 2005; Spinelli et al. 2006). In this research we tested novel management programs utilizing low rates of $\mathrm{PhCa}$ applied at earlier timings, to target blossom and subsequent shoot blight over three growing seasons in a mature planting of
'Gala' trees. These early PhCa programs resulted in less than $27 \%$ incidence of blossom blight and less than $13 \%$ incidence of shoot blight across all three years. Programs were similarly effective during season in which weather conditions greatly favored fire blight development. Although these programs did not provide a level of control equivalent to antibiotic programs, which typically had less than 5\% incidence of blossom blight, they may have utility as part of a comprehensive antibiotic alternative management program because they do not mandate the same level of precise timing as bloom applications for antibiotics. It is also important to note that the $\mathrm{PhCa}$ programs were tested under experimental conditions with high levels inoculum to ensure infection, which are at levels much greater than would occur in most commercial orchards. It is likely that the efficacy of these programs would be greater under the lower inoculum pressures of commercial orchards.

Although not statistically significant, pre-bloom programs of $\mathrm{PhCa}$ applied at the rate of $125 \mathrm{mg} / \mathrm{liter}$ and programs with the biopesticide DN applied at bloom tended to have better control of blossom blight. This product contains the Bacillus amyloliquefaciens strain D747, which acts by producing antibiotic metabolites (Cawoy et al. 2011; Michael Dimock personal communication). Because the most critical stage for infection by E. amylovora is during bloom, it would be an unnecessary risk for a commercial operation to abstain from control measures entirely during this period. Therefore, treatments were selected to include a biopesticide at bloom containing microbial metabolites with antibiotic activity, like DN, to inhibit the pathogen's development on the floral surface as described in other work (Johnson and Temple 2013). In this trial, coupling PhCa with DN only provided increased fire blight control in one year out of three. This strategy may not be justified depending on the associated expenses of the materials and application. Further study is warranted to explore the management implications of $\mathrm{DN}$ and other biopesticides in fire blight control.

In all years and across all treatments, we observed much higher incidences of blossom blight, as compared with shoot blight. This is

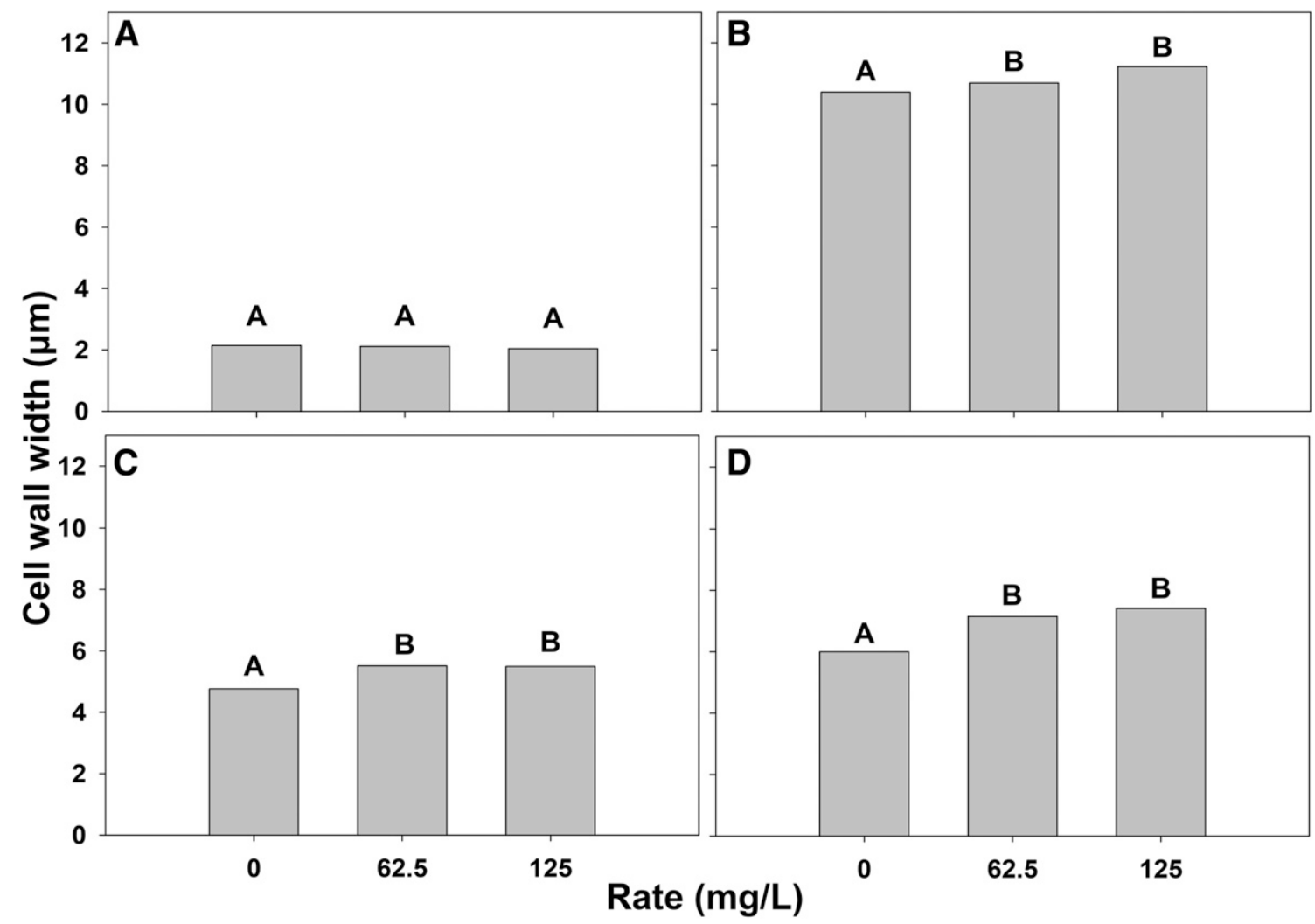

Fig. 2. Mean cell wall thicknesses ( \pm 1 SE) of fruitlet pedicels taken in 2018 (A, B) and 2019 (C, D) for Gala trees treated with prohexadione-calcium (trade name Apogee) at 24 days (A, C) and 47 and 48 days (B, D) after treatment in 2018 and 2019, respectively, at the Cornell AgriTech Research Station in Geneva, NY. Within each graph, different letters above bars indicate significant differences between means based on Tukey HSD test $(P<0.05)$. 
consistent with the established dogma that blossom infections are the more prevalent form of infection and that it is prudent to focus most intensive management programs around the blossom infection stage (Sundin et al. 2009; van der Zwet et al. 2012). Applying PhCa prebloom appeared to have utility in both blossom and shoot blight management and, therefore, offers a desirable solution for commercial management in which elimination or minimization of antibiotics is desired. In contrast, multiple and precisely timed applications of antibiotics, although reliably effective, are time consuming and expensive in terms of labor and wear on equipment and should be used judiciously as part of an integrated management plan.

The mechanism of action of $\mathrm{PhCa}$ has been described as a thickening of the cell walls in the cortical parenchyma of developing shoots, which provides a physical barrier for movement of the pathogen between host cells (McGrath et al. 2009). We found evidence for this cell wall thickening in cross sections of fruitlet pedicels taken both at petal fall (24 days after treatment, one year out of two) and 40 DAFB (50 days after pre-bloom PhCa treatments).

The overall management implications of these findings may be affected by regional and seasonal conditions. Because $\mathrm{PhCa}$ required 10 to 14 days to take effect, the amount of time between applications, phenological stages, and infection periods are critical to the efficacy of these programs, and the duration of phenological stages can vary considerably between regions and years. In this study, the period between pink, when PhCa was applied, and $80 \%$ bloom, when blossom infection would take place, was 8, 12, and 7 days in 2016, 2017, and 2018. From $80 \%$ bloom to petal fall, there was an additional 9, 3, and 11 days during which the bacteria may have entered the flower. This presents an extremely narrow margin for $\mathrm{PhCa}$ applied at pink to take an effect in time to prevent blossom blight. In regions or seasons in which phenology progresses more rapidly, the window would be even smaller, and $\mathrm{PhCa}$ may not have adequate time to take effect. In this case, even earlier applications may be required. On the other hand, blossom blight symptoms often do not appear until much later in the season, indicating that once an infection event occurs (the bacteria are washed into the blossom), more time may be required for the pathogen to establish in the plant and symptoms to develop. This may be related to temperature: E. amylovora has an optimal growth temperature of $28^{\circ} \mathrm{C}$, and reduced growth rates and symptom development are correlated with reduced temperatures (Santander and Biosca 2017; van der Zwet et al. 2012). When the period during bloom is cooler, there may be an adequate slow-down of bacterial growth that allows for the $\mathrm{PhCa}$ effect to take place prior to establishment of infection. In this study, there were 23 to 26 days between inoculation and reliably detectable blossom blight symptoms, suggesting the pathogen was acclimating to the blossom environment and growing during this time period. This lag time is likely to be different in a warmer region or season. Differences in tree growth in different regions, seasons, and under different nutrient management programs may also impact efficacy of pink $\mathrm{PhCa}$ treatment, for shoot blight control especially. It is well established that high vigor (longer shoot growth) is implicated in fire blight infection (van der Zwet et al. 2012). Trees undergoing more shoot growth during infection periods would be expected to be more impacted by $\mathrm{PhCa}$ programs. This would have implications for both disease incidence and horticultural considerations.

Given that the level of fire blight control is correlated with the suppression of growth, the use of $\mathrm{PhCa}$ has been limited to mature orchards and excluded from young plantings being pushed to fill canopy space with vigorous canopy growth (Norelli and Miller 2006, 2004). Use of pre-bloom applications of PhCa in these experiments, rather than timing $\mathrm{PhCa}$ applications when shoot growth averaged 5 to $8 \mathrm{~cm}$ of growth (i.e., post-bloom) as in the majority of previous work (Norelli and Miller 2006, 2004), it appears that this practice is able to take advantage of disease suppression activity during critical infection windows at bloom but allow shoot growth to resume afterward until terminal bud set, reducing the overall impact on tree growth. Certainly, in the present work, overall impact on shoot growth was minimal for pre-bloom PhCa programs. In all three years, there was rarely a difference in shoot length, and any differences observed were on the order of only a few centimeters. This magnitude of growth is arguably not horticulturally significant and may not have an impact on orchard establishment.

The results found here demonstrate potential for pre-bloom $\mathrm{PhCa}$ management programs for managing fire blight in commercial orchards. These programs provided control of fire blight with minimal impact to shoot growth. However, these programs must be evaluated in a variety of production settings (regions, cultivars, rootstocks, production systems, age of planting, etc.) in order to determine their efficacy in different climates and production systems. Further, these programs should be tested in commercial orchards, both to evaluate effects in these systems and to facilitate adoption by commercial growers.

\section{Acknowledgments}

We thank the Cornell AgriTech FRU personnel for maintaining the trees and Mei-Wah Choi, Katrin Ayer, David Strickland, John Spafford, Daniel Kaplan, and Jenna Happach for assisting with data collection.

\section{Literature Cited}

Agnello, A., Brown, B., Carroll, D., Cheng, L., Cox, K., Curtis, P., Helms, M., Kain, D., and Robinson, T. 2019. Cornell Pest Management Guidelines for Commercial Tree Fruit Production. PMEP, Cornell University, Ithaca, NY.

Aldwinckle, H., Robinson, T., Norelli, J., Momol, T., and Reddy, B. 2000 Controlling shoot blight with 'Apogee.'. NY Fruit Q. 8:4.

Aldwinckle, H. S., Bhaskara Reddy, M. V., and Norelli, J. L. 2002. Evaluation of control of fire blight infections of apple blossoms and shoots with SAR inducers, biological agents, a growth regulator, copper compounds, and other materials. Acta Hortic. 590:325-331.

Bazzi, C., Messina, C., Tortoreto, L., Stefani, E., Bini, F., Brunelli, A., et al. 2003. Control of pathogen incidence in pome fruits and other horticultural crop plants with prohexadione-Ca. Eur. J. Hortic. Sci. 68:108-114.

Biggs, A. R., and Turechek, W. W. 2010. Fire blight of apples and pears: Epidemiological concepts comprising the Maryblyt forecasting program. Plant Health Prog. 11:23.

Breth, D. I., Momol, M. T., and Aldwinckle, H. S. 1998. Evaluation of BAS 125 for the control of fire blight in apple shoots. Fungicide Nematic. Tests. 53:4.

Buban, T., Beszeda, E., Dorgai, L., Földes, L., Hudak, I., Dobranszki, J., et al. 2006. Erwinia amylovora infection of flowers and shoots in apple trees treated with prohexadione-Ca. Acta Hortic. 704:271-276.

Carroll, J., Weigle, T., Agnello, A., Reissig, H., Cox, K., Breth, D., et al. 2017. NEWA (Network for Environment and Weather Applications) provides fruit IPM and production tools from 400 weather stations. NY Fruit Q. 25:19-24.

Cawoy, H., Bettiol, W., Fickers, P., and Ongena, M. 2011. Bacillus-Based Biological Control of Plant Diseases, Pesticides in the Modern World-Pesticides Use and Management. Margarita Stoytcheva, IntechOpen, London, U.K.

Costa, G., Andreotti, C., Bucchi, F., Sabatini, E., Bazzi, C., Malaguti, S., et al. 2001. Prohexadione-Ca (Apogee $($ ): Growth regulation and reduced fire blight incidence in pear. HortScience 36:931-933.

Costa, G., Sabatini, E., Spinelli, F., Andreotti, C., Bomben, C., and Vizzotto, G. 2004. Two years of application of prohexadione-Ca on apple: Effect on vegetative and cropping performance, fruit quality, return bloom, and residual effect. Acta Hortic. 653:35-40.

Evans, J. R., Evans, R. R., Regusci, C. L., and Rademacher, W. 1999. Mode of action, metabolism, and uptake of BAS $125 \mathrm{~W}$, prohexadione-calcium. HortScience 34:1200-1201.

Flachowsky, H., Halbwirth, H., Treutter, D., Richter, K., Hanke, M.-V., Szankowski, I., et al. 2012. Silencing of flavanone-3-hydroxylase in apple (Malus $\times$ domestica Borkh.) leads to accumulation of flavanones, but not to reduced fire blight susceptibility. Plant Physiol. Biochem. 51:18-25.

Greene, D. W. 2005. Carryover effects of prohexadione-calcium on apples. HortScience 40:1340-1342.

Halbwirth, H., Fischer, T. C., Roemmelt, S., Spinelli, F., Schlangen, K., Peterek, S., Sabatini, E., Messina, C., Speakman, J., Andreotti, C., Rademacher, W., Bazzi, C., Costa, G., Treutter, D., Forkmann, G., and Stich, K. 2003. Induction of antimicrobial 3-deoxyflavonoids in pome fruit trees controls fire blight. Z. Naturforsch., C 58:765-770.

Johnson, K. B., and Temple, T. N. 2013. Evaluation of strategies for fire blight control in organic pome fruit without antibiotics. Plant Dis. 97:402-409.

Jones, A. L., Fernanado, W. G. D., and Ehret, G. R. 1999. Controlling secondary spread of fire blight with prohexadione calcium. Phytopathology 89:S37.

Lee, S. A., Ngugi, H. K., Halbrendt, N. O., O' Keefe, G., Lehman, B., Travis, J. W., et al. 2010. Virulence characteristics accounting for fire blight disease severity in apple trees and seedlings. Phytopathology 100:539-550.

Loper, J., Henkels, M., Roberts, R., Grove, G., Willet, M., and Smith, T. 1991. Evaluation of streptomycin, oxytetracycline, and copper resistance of Erwinia amylovora isolated from pear orchards in Washington State. Plant Dis. 75: 287-290. 
McGhee, G. C., Guasco, J., Bellomo, L. M., Blumer-Schuette, S. E., Shane, W. W., Irish-Brown, A., et al. 2011. Genetic analysis of streptomycin-resistant (SmR) strains of Erwinia amylovora suggests that dissemination of two genotypes is responsible for the current distribution of SmR E. amylovora in Michigan. Phytopathology 101:182-191.

McGhee, G. C., and Sundin, G. W. 2011. Evaluation of kasugamycin for fire blight management, effect on nontarget bacteria, and assessment of kasugamycin resistance potential in Erwinia amylovora. Phytopathology 101:192-204.

McGrath, M. J., Koczan, J. M., Kennelly, M. M., and Sundin, G. W. 2009. Evidence that prohexadione-calcium induces structural resistance to fire blight infection. Phytopathology 99:591-596.

McManus, P. S., and Jones, A. L. 1994. Epidemiology and genetic analysis of streptomycin-resistant Erwinia amylovora from Michigan and evaluation of oxytetracycline for control. Phytopathology 84:627-633.

McManus, P. S., Stockwell, V. O., Sundin, G. W., and Jones, A. L. 2002. Antibiotic use in agriculture. Annu. Rev. Phytopathol. 40:443-465.

U. Meier, ed. 2001. Growth Stages of Mono- and Dicotyledonous Plants. BBCH Monograph, 2nd Ed. Blackwell, Berlin, Germany.

Miller, T. D., and Scroth, M. N. 1972. Monitoring the epiphytic population of Erwinia amylovora on pear with selective medium. Phytopathology 62: 1175-1182.

Norelli, J. L. 2003. Fire blight management in the twenty-first century. Plant Dis. 87:756-765.

Norelli, J. L., and Miller, S. S. 2004. Effect of prohexadione-calcium dose level on shoot growth and fire blight in young apple trees. Plant Dis. 88: 1099-1106.

Norelli, J. R., and Miller, S. S. 2006. Using prohexadione-calcium to control fire blight in young apple trees. In: X International Workshop on Fire Blight. Acta Hortic. 704:217-224.

Rademacher, W., and Kober, R. 2003. Efficient use of prohexadione-Ca in pome fruits. Eur. J. Hortic. Sci. 68(3)S:101-107.

Rademacher, W., Spinelli, F., and Costa, G. 2006. Prohexadione-Ca: Modes of action of a multifunctional plant bioregulator for fruit trees. In: $X$ International Symposium on Plant Bioregulators in Fruit Production. Acta Hortic. 727:97-106.

Roemmelt, S., Zimmermann, N., Rademacher, W., and Treutter, D. 2003. Formation of novel flavonoids in apple (Malus $\times$ domestica) treated with the 2-oxoglutarate-dependent dioxygenase inhibitor prohexadione-Ca. Phytochemistry 64:709-716

Russo, N. L., Burr, T. J., Breth, D. I., and Aldwinckle, H. S. 2008. Isolation of streptomycin-resistant isolates of Erwinia amylovora in New York. Plant Dis. 92:714-718.

Santander, R. D., and Biosca, E. G. 2017. Erwinia amylovora psychotropic adaptations: Evidence of pathogenic potential and survival at temperate low environmental temperatures. PeerJ 5:e3931.

Schupp, J., Rosenberger, D., Robinson, T., Aldwinckle, H., Norelli, J., and Porpiglia, P. 2002. Post-symptom sprays of prohexadione-calcium affect fire blight infection of 'Gala' apple on susceptible or resistant rootstock. HortScience 37:903-905.

Smith, T. J. 1999. Report on the development and use of Cougarblight 98C-A situation-specific fire blight risk assessment model for apple and pear. Acta Hortic. 489:429-436.

Spinelli, F., Andreotti, C., Sabatini, E., Costa, G., Spada, G., Ponti, L., et al. 2006 Chemical control of fire blight in pear: Application of prohexadione-calcium, acibenzolar-S-methyl, and copper preparations in vitro and under field conditions. Acta Hortic. 704:233-238.

Spinelli, F., Vanneste, J. L., Marcazzan, G. L., Sabatini, A. G., and Costa, G. 2005. Effect of prohexadione-calcium on nectar composition of pomaceous flowers and on bacterial growth. Fruit Dis. Manage., N. Z. Plant Prot. 58:106-111.

Sundin, G. W., Werner, N. A., Yoder, K. S., and Aldwinckle, H. S. 2009. Field evaluation of biological control of fire blight in the eastern United States. Plant Dis. 93:386-394.

Tancos, K. A., and Cox, K. D. 2016. Exploring diversity and origins of streptomycin-resistant Erwinia amylovora isolates in New York through CRISPR spacer arrays. Plant Dis. 100:1307-1313.

Turechek, W. W., and Biggs, A. R. 2015. Maryblyt v. 7.1 for Windows: An improved fire blight forecasting program for apples and pears. Plant Health Prog. 16:16-22.

van der Zwet, T., Orolaza-Halbrendt, N., and Zeller, W. 2012. Pages 5-11, 15-29, 155-159, and 333-347 in: Fire Blight History, Biology, and Management. American Phytopathological Society, St. Paul, MN.

Yoder, K. S., Miller, S. S., and Byers, R. E. 1999. Suppression of fireblight in apple shoots by prohexadione-calcium following experimental and natura inoculation. HortScience 34:1202-1204. 